\title{
KARAKTERISTIK FISIKOKIMIA MIE JAGUNG PULUT (Zea mays Ceritina) DENGAN PENAMBAHAN TEPUNG IKAN CAKALANG (Katsuwonus pelamis)
}

\author{
Satria Wati Pade ${ }^{1}$, Nurfitriyanti Bulotio ${ }^{2}$ \\ 1. Dosen Program Studi D3 Teknologi Hasil Pertanian, Politeknik Gorontalo \\ 2. Dosen Program Studi D3 Teknologi Hasil Pertanian, Politeknik Gorontalo \\ Jl. Muchlis Rahim Desa Panggulo, Kecamatan Botupingge Kabaputaen Bone Bolango, Provinsi Gorontalo \\ E-mail : indonk@ poligon.ac.id ${ }^{1)}$
}

\begin{abstract}
ABSTRAK
Jagung merupakan salah satu jenis komoditi penting di Indonesia. Komoditas jagung saat ini menjadi komoditas nasional yang cukup strategis (Kementan, 2016). Menurut BPS (2017) produksi jagung di Gorontalo tahun 2015 cukup melimpah tercatat 643.513 ton. Akan tetapi, pada skala petani atau usaha kecil menengah, jagung umumnya hanya dijual begitu saja sebagai kudapan atau makanan ringan. Untuk meningkatkan nilai tambah dan pemanfaatan dari jagung maka dapat dilakukan pengolahan jagung menjadi produk-produk turunannya diantaranya diolah menjadi tepung jagung yang dapat diolah lebih lanjut menjadi bahan dasar dalam pembuatan mie basah.

Mie merupakan produk makanan dengan bahan baku tepung terigu sangat populer di kalangan masyarakat Indonesia. Produk mie yang berbahan dasar tepung terigu memiliki karbohidrat cukup tinggi akan tetapi kadar proteinnya kurang. Salah satu sumber protein yang cukup tinggi dan mudah didapat yaitu ikan cakalang yang dapat ditambahkan dalam mie basah.

Penelitian ini menggunakan metode rancangan acak lengkap yang terdiri atas tiga perlakuan yaitu perlakuan $\mathrm{A}=$ tepung jagung pulut $200 \mathrm{gr}+$ tepung terigu $800 \mathrm{gr}+$ tepung ikan cakalang $50 \mathrm{gr}$, perlakuan $\mathrm{B}=$ tepung jagung pulut $400 \mathrm{gr}+$ tepung terigu $600 \mathrm{gr}+$ tepung ikan cakalang $50 \mathrm{gr}$, C=tepung jagung pulut $600 \mathrm{gr}+$ tepung terigu $400 \mathrm{gr}$ + tepung ikan cakalang 50 gr, masing-masing perlakuan diulang sebanyak tiga kali. Variabel yang diamati meliputi : kadar protein, kadar air, kadar abu, warna dan daya pengembangan. Hasil penelitian menunjukkan ratarata kadar protein $6,47 \%$, kadar air 50,43\%, kadar abu 0,64\%, warna berkisar antara 2,8-3,4 atau taraf tidak suka sampai netral dan daya pengembangan berkisar antara10,8-28,50\%.
\end{abstract}

Kata kunci : mie basah, jagung pulut, ikan cakalang

\begin{abstract}
Corn is one of important commodities in Indonesia. Commodity of corn is currently a strategic national commodity (Kementan, 2016). According to BPS (2017), maize production in Gorontalo 2015 is quite abundant with 643,513 tons recorded. However, on the scale of farmers or small to medium-sized businesses, corn is generally sold simply as a snack. To increase the added value and utilization of corn, corn processing can be processed into derivative products such as processed into corn flour which can be further processed into basic material in making wet noodles

Noodle is a food product with wheat flour raw material is very popular among the people of Indonesia. Noodle products made from wheat flour have high carbohydrate but the protein content is less. One source of high enough protein and easily available is skipjack that can be added in wet noodles.

This study used a complete randomized design method consisting of three treatments, treatment $A=200 \mathrm{gr}$ wax corn flour + wheat flour $800 \mathrm{gr}+$ skipjack flour $50 \mathrm{gr}$, treatment $B=$ wax corn flour $400 \mathrm{gr}+$ wheat flour $600 \mathrm{gr}$ + skipjack flour $50 \mathrm{gr}$, treatment $C=$ wax corn flour $600 \mathrm{gr}+$ wheat flour $400 \mathrm{gr}+$ skipjack flour $50 \mathrm{gr}$, each treatment repeated three replications. The variables observed were: protein content, water content, ash content, color and development power. The results showed average protein content of $6.47 \%$, water content $50.43 \%$, ash content $0.64 \%$, color ranged from 2.8-3.4 or dislike to neutral level and development power ranged between 10.8 $-28,50 \%$
\end{abstract}

Key words : wet noodles, wax corn, skipjack 


\section{Pendahuluan}

Jagung merupakan salah satu jenis komoditi penting di Indonesia. Selain beras, jagung menjadi komoditi utama hampir sebagian masyarakat Indonesia. Hal ini terbukti masyarakat di beberapa daerah di Indonesia, menjadikan jagung sebagai bahan pangan utama. Komoditas jagung saat ini menjadi komoditas nasional yang cukup strategis (Kementan, 2016). Menurut BPS (2017), produksi jagung di Gorontalo tahun 2015 cukup melimpah tercatat 643.513 ton.

Pemanfaatan jagung untuk industri pangan sudah cukup berkembang dan bervariasi antara lain makanan ringan, minyak jagung, maizena, grits, margarin, gula dan lain sebagainya. Akan tetapi, pada skala petani atau usaha kecil menengah, jagung umumnya hanya dijual begitu saja sebagai kudapan atau makanan ringan. Untuk meningkatkan nilai tambah dan pemanfaatan dari jagung maka dapat dilakukan pengolahan jagung menjadi produkproduk turunannya diantaranya diolah menjadi tepung jagung yang dapat diolah lebih lanjut menjadi bahan dasar dalam pembuatan mie basah.

Mie merupakan produk makanan dengan bahan baku tepung terigu sangat populer di kalangan masyarakat Indonesia. Produk mie yang berbahan dasar tepung terigu memiliki karbohidrat cukup tinggi akan tetapi kadar proteinnya kurang. Untuk mengatasi hal tersebut, diperlukan alternative bahan pangan lain sebagai substitusi dalam pembuatan mie untuk melengkapi nutrisi yang masih kurang dalam produk mie basah. Salah satu sumber protein yang cukup tinggi dan mudah didapat yaitu ikan cakalang yang dapat ditambahkan dalam mie basah. Penggunaan ikan cakalang sebagai sumber protein sesuai dengan habitat ikan cakalang yang banyak ditemukan diperairan Indonesia.

Berdasarkan hal tersebut dipandang perlu dilakukan penelitian tentang karakteristik fisikokimia mie jagung pulut dengan penambahan ikan cakalang.

\section{Metodologi}

Alat : mesin penggiling, tirisan, wajan, wadah, talenan, pengaduk, timbangan analitik, oven, cawan porselen, mortal, tanur dan alat-alat analisa lainnya..

Bahan : jagung pulut, air, tepung terigu, telur, cakalang, minyak kelapa, garam dan bahan-bahan analisis.

\subsection{Metodologi Penelitian}

Penelitian ini menggunakan metode rancangan acak lengkap (RAL) dengan tiga perlakuan konsentrasi starter yaitu :

A : tepung jagung pulut $200 \mathrm{gr}+$ tepung terigu 800 gr + tepung ikan cakalang 50 gr

B : tepung jagung pulut $400 \mathrm{gr}+$ tepung terigu 600 gr + tepung ikan cakalang $50 \mathrm{gr}$

$\mathrm{C}$ : tepung jagung pulut $600 \mathrm{gr}+$ tepung terigu 400 gr + tepung ikan cakalang $50 \mathrm{gr}$

masing-masing perlakuan diulang sebanyak tiga kali. Penelitian ini terbagi atas tiga tahap yaitu pembuatan tepung jagung, pembuatan tepung ikan dan pembuatan mie jagung pulut.

\section{Prosedur Kerja}

3.1. Pembuatan tepung jagung

a) Jagung ditimbang sebanyak 1000 gram.

b) Jagung direndam dengan tambahan kapur 5 gram selama 24 jam.

c) Kemudian dikeringkan di dalam dry oven selama 3 jam dengan suhu $65{ }^{\circ} \mathrm{C}$.

d) Setelah dikeringkan kemudian digiling menggunakan mesin penggiling.

e) Setelah itu dilakukan pengayakan dengan ayakan 50 mesh.

f) Kemudian tepung dikeringkan kembali agar tidak terjadi pembusukan.

3.2. Pembuatan tepung ikan cakalang

a) Ikan di bersihkan dan di lakukan penyiangan,pemfiletan.

b) Ikan dikukus pada suhu pada suhu $80{ }^{\circ} \mathrm{C}$.

c) Ikan yang telah dikukus dipress selama 10 menit dan kemudian dikeringkan dalam oven pada suhu $50{ }^{\circ} \mathrm{C}$ selama 5 jam.

d) dilakukan penepungan dengan ukuran 60 mesh

3.3. Pembuatan mie jagung pulut

a) Tahap awal pembuatan mie diawali dengan pencampuran bahan yang terdiri dari tepung jagung, tepung ikan cakalang dan tepung terigu sesuai dengan konsentrasi yang telah ditentukan.

b) Ditambahkan bahan bahan berupa air dan telur dan diaduk sampai kalis.

c) Proses dilanjutkan dengan proses pencetakan menjadi untaian mie 
4. Hasil dan Pembahasan

\subsection{Protein}

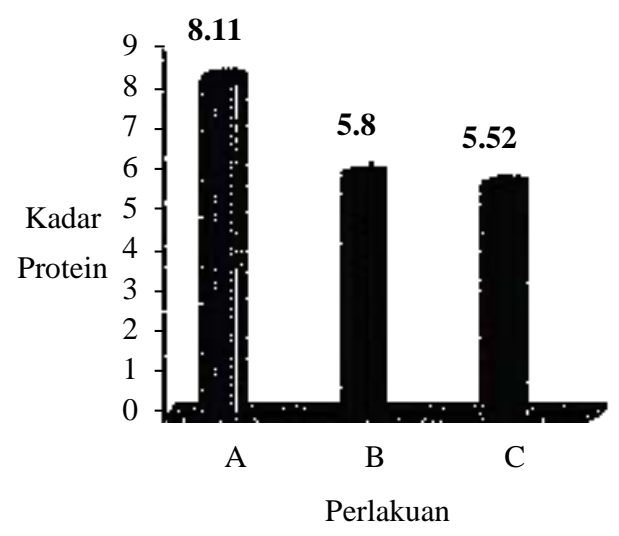

Gambar 1. Diagram Kadar Protein Mie Jagung Pulut

Gambar 1 menunjukkan bahwa, nilai ratarata kadar protein yang tertinggi dimiliki oleh perlakuan A yaitu sebesar $8,11 \%$, sedangkan nilai rata-rata kadar protein yang terendah dimiliki oleh perlakuan $\mathrm{C}$ yaitu sebesar $5,52 \%$. Hasil penelitian menunjukkan bahwa, kadar protein menurun seiring dengan berkurangnya jumlah komposisi tepung terigu dan bertambahnya komposisi tepung jagung pulut. Hal ini sesuai dengan pendapat Suarni (2003) bahwa kandungan protein yang ada dalam tepung jagung pulut sebesar 6,79\%. Sedangkan menurut Astawan (2006), kandungan protein yang ada dalam tepung terigu sebesar $8 \%$. Sehingga perlakuan A lebih tinggi kadar protein dibandingkan dengan perlakuan yang lain.

Dari ketiga perlakuan ini, perlakuan A yang memenuhi SNI mie basah yaitu minimal $8 \%$. Rendahnya kadar protein dari mie jagung pulut disebabkan oleh kandungan protein pada bahan yang digunakan juga rendah. Selain itu, protein yang ada dalam bahan terdenaturasi akibat suhu panas. Menurut Kusnandar (2011), denaturasi protein adalah terjadinya modifikasi sturktur sekunder, tersier dan kuartener dari protein tanpa pemutusan ikatan peptide.

\subsection{Kadar Air}

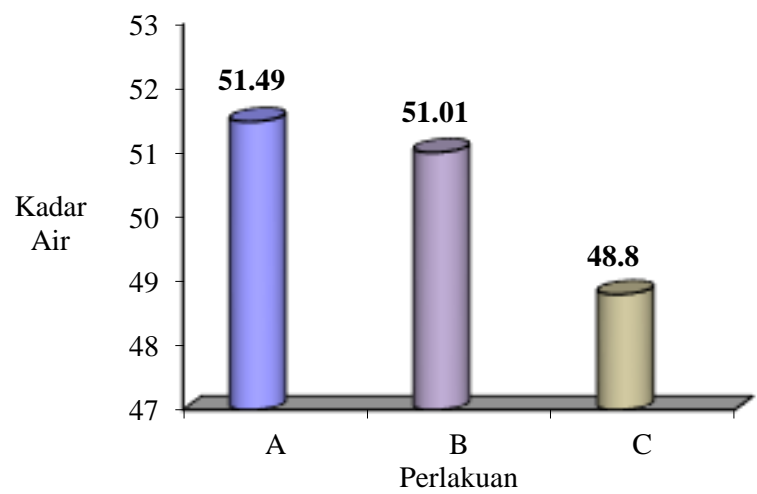

Gambar 2. Diagram Kadar Air Mie Jagung Pulut

Gambar 2 menunjukkan bahwa rata-rata kadar air berkisar antara 48,8-51,49\%. Kadar air tertinggi yaitu pada perlakuan A sebesar $51,49 \%$ dan terendah pada perlakuan $\mathrm{C}$ sebesar $48,8 \%$.

Berdasarkan analisis statistic, perbedaan perlakuan pada pembuatan mie jagung pulut dengan subtitusi tepung ikan cakalang berpengaruh sangat nyata terhadap kadar air yang dihasilkan. Hal ini disebabkan oleh banyaknya kosentrasi bahan utama yang ditambahkan pada masing-masing perlakuan berbeda. Pada perlakuan A, tepung jagung pulut yang ditambahkan sebanyak 200 gram, tepung terigu 800 gram dan tepung ikan cakalang 50 gram. Sedangkan pada perlakuan $\mathrm{C}$, tepung jagung pulut yang ditambahkan sebanyak 600 gram, tepung terigu 400 gram dan tepung ikan cakalang 50 gram. Penambahan tepung terigu dalam jumlah yang banyak menghasilkan kadar air yang tinggi dibandingkan dengan penambahan tepung jagung pulut dalam jumlah yang banyak. Semakin sedikit penambahan tepung terigu pada masing-masing perlakuan, maka kadar air dari mie semakin berkurang. Hal ini sesuai dengan pendapat Gaman dan Sherington (1994), peningkatan kadar protein selalu diikuti dengan peningkatan kadar air produk. Hal yang sebaliknya juga berlaku semakin rendah kadar protein semakin rendah pula kadar air produk.

Hasil penelitian menunjukkan bahwa, nilai rata-rata kadar air mie jagung pulut dengan subtitusi tepung terigu berkisar antara 48,80 - 51,49\% dan berdasarkan SNI mie basah (SNI 01-2987-1992). 


\subsection{Kadar Abu}

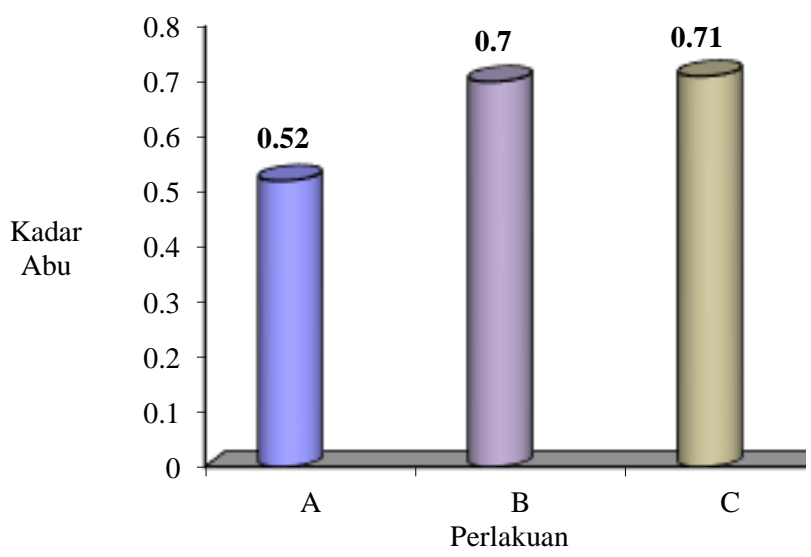

Gambar 3. Diagram Kadar Abu Mie Jagung Pulut

Gambar 3 menunjukkan bahwa nilai rata-rata kadar abu mie jagung pulut berkisar antara 0,52 $0,71 \%$. Nilai rata kadar abu tertinggi dimiliki oleh C yaitu $0,71 \%$. Sedangkan nilai rata-rata kadar abu yang terendah dimiliki oleh perlakuan A yaitu $0,52 \%$. Perbedaan ini disebabkan oleh kandungan abu yang terdapat pada tepung jagung pulut lebih besar dibandingkan dengan kadar abu yang terdapat pada tepung terigu. kandungan abu yang terdapat dalam tepung jagung pulut sebesar 1,99\%. Sedangkan kandungan abu yang terdapat dalam tepung terigu menurut Astawan (2006) adalah $0,25 \%$. Sehingga perlakuan $\mathrm{C}$ lebih tinggi kadar abunya dibandingkan dengan perlakuan A dan B.

Dari hasil penelitian yang dilakukan, ketiga perlakuan pembuatan mie jagung pulut dengan subtitusi tepung terigu dan penambahan tepung ikan cakalang sudah memenuhi SNI dari mie basah yaitu maksimal 3\%. Rendahnya kadar abu yang dihasilkan dari pembuatan mie jagung ini disebabkan oleh kandungan abu yang terdapat dalam bahan dasar maupun bahan tambahan juga rendah.

\subsection{Warna}

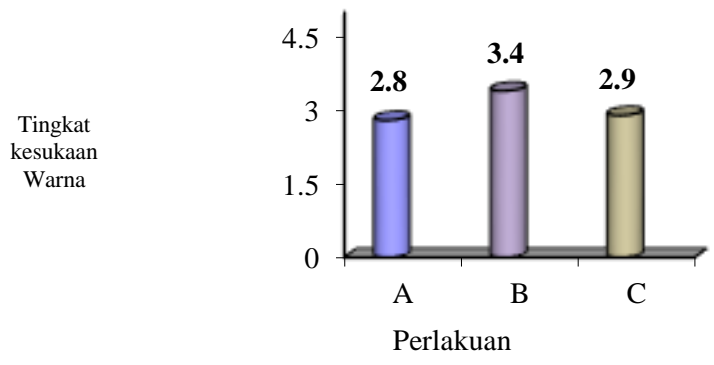

Gambar 4. Diagram Tingkat kesukaan Terhadap warna mie jagung pulut Jagung
Gambar 4 menunjukkan bahwa , bahwa tingkat kesukaan panelis terhadap warna mie jagung pulut berkisar pada skor 2,8-3,4 atau pada taraf tidak suka sampai netral. Dilihat dari gambar diagram di atas, formulasi B yang disukai oleh panelis dibandingkan dengan formulasi yang lainnya. Hal ini karena, warna mie basah semakin meningkat seiring dengan meningkatnya tepung terigu yang ditambahkan. Hal ini dikarenakan warna mie basah yang ditambahkan tepung terigu lebih kelihatan cerah daripada warna mie yang ditambahkan tepung jagung pulut yang lebih banyak. Selain itu, adanya penambahan tepung ikan cakalang akan menyebabkan warna dari mie agak gelap. Hal ini karena, tepung ikan cakalang warna dasarnya berwarna coklat.

\subsection{Daya Pengembangan}

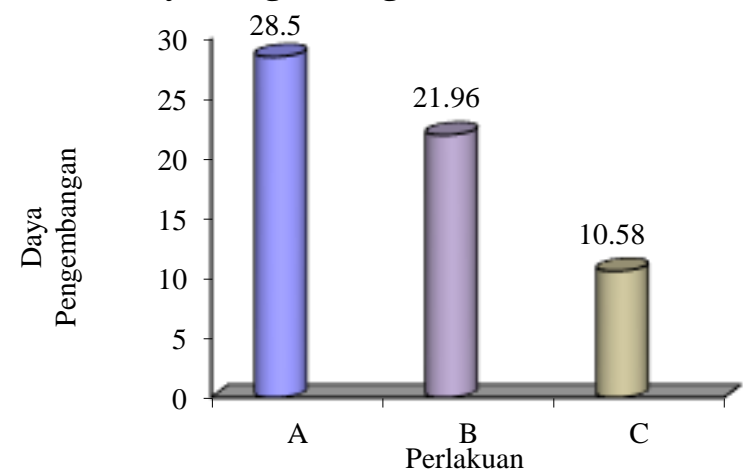

Gambar 5. Diagram Daya Pengembangan Mie Jagung Pulut

Gambar 5 menunjukkan bahwa nilai rata-rata daya pengembangan mie basah berkisar antara 10,8-28,5 . Perbedaan perlakuan pembuatan mie basah dengan subtitusi tepung jagung pulut dan penambahan tepung ikan cakalang tidak berbeda nyata terhadap daya pengembangan yang diperoleh.

Nilai rata-rata pengembangan yang tertinggi terdapat pada perlakuan A (200 gr tepung jagung : 800 gr tepung terigu : 50 gr tepung ikan cakalang) yaitu 28,50 . Sedangakan nilai rata-rata terendah terdapat pada perlakuan $\mathrm{C}(600$ gr tepung jagung : 400 gr tepung terigu : 50 gr tepung ikan cakalang) yaitu 10,58. Semakin meningkat jumlah tepung jagung maka daya mengembang semakin menurun. sebaliknya, semakin meningkat jumlah tepung terigu maka daya mengembang semakin tinggi. Hal ini disebabkan pati dari tepung terigu lebih mudah menyerap air dibandingkan pati dari tepung jagung. Menurut Singarimbun (2008), pati tepung terigu jika dipanaskan lebih mudah mengembang dibandingkan dengan pati tepung jagung. Pengembangan ini disebabkan oleh granula-granula pati pada tepung tergenisasi.

Sehingga formulasi A lebih tinggi daya pengembangannya dibandingkan formulasi yang lain. 


\section{Kesimpulan}

Berdasarkan hasil penelitian maka dapat diambil beberapa kesimpulan sebagai berikut :

1. Dari hasil analisis sifat kimia yang dilakukan nilai gizi mie jagung pulut diperoleh rata-rata kadar protein $6,47 \%$, kadar air $50,43 \%$ dan kadar abu $0,64 \%$. Ketiga perlakuan tersebut sudah memenuhi Syarat Mutu SNI .

2. Berdasarkan uji organoleptik mie jagung pulut pada semua perlakuan, tingkat kesukaan terhadap warna berkisar antara 2,8 -3,4. Pada uji pengembangan, formula A memiliki daya pengembangan terbaik yaitu $28,5 \%$.

\section{Daftar Pustaka}

Astawan, M. 2006. Membuat Mie dan Bihun. Penebar Swadaya. Bogor.

Badan Pusat Statistik (BPS). 2018. Produksi Jagung Tahun 2015. https://gorontalo.bps.go.id/pressrelease/2016 /07/01/342/produksi-jagung-tahun-2015sebanyak-643-513-ton-pipilan-kering.html. Diakses pada tanggal 3 Februari 2017.

Gaman, P.M dan K.B Sherrington. 1994. Pengantar Ilmu Pangan, Nutrisi dan Mikrobiologi. Gadjah Mada University Press. Yogyakarta.

Kementerian Pertanian (Kementan). 2016. Komoditas Pertanian Sub Sector Pangan. http://perpustakaan.bappenas.go.id/lontar/fi le $?$ file $=$ digital/166967. Diakses pada tanggal 5 April 2017.

SNI. 1992. Mutu Dan Cara Uji Mie Basah. Badan Standarisasi Nasional.

Singarimbun, A. 2008. Pengaruh Perbandingan Tepung Terigu Dengan Tepung jagung dan Konsentari Kalium Sorbet Terhadap Mutu Mie Basah (Boiled Noodle). Universitas Sumatra Utara.

Suarni. 2003. Jagung pulut : Pemanfaatan dan pengolahan sebagai bahan pangan lokal potensial di Sulawesi Selatan. Prosiding Seminar Nasional Tahunan PERTETA, BPTTG LIPI. Bandung. 